\title{
DISSEMINATED CEREBRAL THROMBOTIC MICROANGIOPATHY IN A PATIENT WITH ADULT'S STILL DISEASE
}

\author{
Renan B. Domingues', Ana Maria Casati da Gama², Eliana B. Caser², \\ Carlos Musso ${ }^{3}$, Maria Carmen S. Santos ${ }^{3}$
}

\begin{abstract}
Objective: The aim of this report is to describe a fatal disseminated thrombotic micoangiopathy with renal, pancreatic, and cerebral involvement in a patient with recently diagnosed adult's Still disease (ASD). Case report: A previously healthy 15 year old girl was admitted to our hospital. According to the clinical and laboratory data the diagnosis of adult's still Disease was established. The treatment was begun and few days after an initial improvement a sudden neurologic deterioration with coma and seizures has occurred. Hours later the patient died. Clinical, laboratorial, and pathologic data will be presented. Conclusion: To our knowledge this is the second description of a fatal disseminated cerebral thrombotic microangiopathy in a patient with adult's Still disease, but with a much more fulminating evolution than previously reported. Some etiopathogenic mechanisms could be shared in these two disorders explaining this coexistence.
\end{abstract}

KEY WORDS: adult's Still disease, cerebral thrombotic microangiopathy, thrombotic thrombocitopenic purpura.

\section{Microangiopatia trombótica cerebral em um paciente com doença de Still do adulto}

RESUMO - Objetivo: O objetivo deste estudo é relatar um caso fatal de microangiopatia trombótica, com envolvimento dos rins, pâncreas e cérebro, concomitantemente a um quadro recém diagnosticado de doença de Still do adulto. Caso: Uma paciente de 15 anos, previamente saudável, foi admitida em nosso serviço. Os dados clínicos e laboratoriais levaram ao diagnóstico de doença de Still do adulto. Após alguns dias do início do tratamento e uma melhora inicial, houve súbita deterioração do nível de consciência e convulsões, tendo a paciente evoluido para o óbito horas após. Os dados clínicos, laboratoriais e anátomo patológicos serão apresentados. Conclusão: Trata-se do segundo caso fatal de microangiopatia trombótica fatal em paciente com doença de Still do adulto, mas com evolução neurológica muito mais rápida e fulminante que no caso anteriormente descrito. Mecanismos etiopatogenéticos comuns poderiam explicar a coexistência destas duas doenças.

PALAVRAS-CHAVE: doença de Still do adulto, púrpura trombocitogênica trombótica, microangiopatia trombótica.

Adult's Still disease (ASD) has been recognized as a cause of fever, arthritis, evanescent maculopapular rash, myalgia, serositis, and leukocytosis. No specific serologic abnormalities or definitive etiology has been determined. The diagnosis of ASD is based on clinical findings as well as exclusion of other febrile polyarthritis ${ }^{1}$. Central nervous system manifestations have been described and include pyramidal tract signs, cranial nerve disorders, seizures, brainstem hemorrhage, and peripheral neuropathy. Some of these abnormalities are associated with drug toxicity, infections, or vasculitis².
Here we report a patient with ASD who developed an acute neurological disease with intracranial hypertension associated with acute pancreatitis and acute renal failure. This fatal systemic disease was due to a disseminated thrombotic microangiopathy disease compatible with thrombotic thrombocitopenic purpura (TTP)/adult hemolytic uremic syndrome (HUS) (HUS/TTP syndrome).

\section{CASE}

A 15 year-old girl was admitted to the hospital with a 2-months history of intermittent high fever, migratory

${ }^{1}$ Professor-Adjunto, Escola de Medicina da Santa Casa de Misericórdia de Vitória, Vitória ES, Brasil; ${ }^{2}$ Departamento de Clínica Médica, Universidade Federal do Espírito Santo (UFES), Vitória ES, Brasil; ${ }^{3}$ Departamento de Patologia, UFES. 
polyarthritis involving her wrists, knees, and ankles, evanescent macular skin rash, myalgias, and prostration. There were not lymphoadepathy and hepatoesplenomegaly. The neurologic examination was initially normal. The white blood cell (WBC) count was $28,500 / \mathrm{mm} 3$ (90\% neutrophils), platelets $440,000 / \mathrm{mm} 3$, hemoglobin $9.4 \mathrm{gm} / \mathrm{dl}$, reticulocyte count was $3,7 \%$. Prothrombin activity (PA) was $72 \%$, activated partial thomboplastin (APTT) time was 30 s. Blood urea was $18 \mathrm{mg} / \mathrm{dl}$, creatinine $0.7 \mathrm{mg} / \mathrm{dl}$; indirect and direct bilirrubin were 0.2 and $0.3 \mathrm{mg} / \mathrm{dl}$, respectively; serum glutamic oxalacetic transaminase (SGOT) $32 \mathrm{IU}$, serum glutamic pyruvic transaminase (SGPT) 38 IU; amylase $30 \mathrm{U} / \mathrm{l}$; urianalysis revealed 8-10 white cells per field and protein traces. Blood and urine cultures were negative. Anti-streptolysis $\mathrm{O}$ titer was within normal values, antibodies to nuclear antigens, complement levels, and VDRL were negative. HIV antibodies, hepatitis B surface antigen, and hepatitis $C$ antibodies were negative. Chest radiography, eletrocardiogram, and transthoracic echocardiogram were normal.

She was initially treated with aspirin (3g/day) and prednisone ( $30 \mathrm{mg} /$ day). Within $48 \mathrm{~h}$ there was a marked improvement in arthritis and constitutional symptoms. Thirteen days later the patient became suddenly confuse and agitated. Few minutes later a tonic-clonic generalized seizure was registered. She remained comatose after the seizure. Acute renal failure (blood urea $174 \mathrm{mg} / \mathrm{dl}$, creatinine 5.7 $\mathrm{mg} / \mathrm{dl}$ ) and pancreatitis (amylase $2831 \mathrm{U} / \mathrm{l}$ ) were detected at this time. The WBC count was $64,100 / \mathrm{mm} 3$, platelets $84,000 / \mathrm{mm} 3$. Prothrombin activity was $70 \%$, activated partial thomboplastin time was $35 \mathrm{~s}$. Urinary albumina was significantly increased $(+++/ 4+)$. Therapy with methilprednisolone $1000 \mathrm{mg} /$ day was initiated. However, one day later her neurologic examination showed Glasgow coma scale 3, and bilateral paralytic midriasis.

Macroscopic findings at autopsy were acute fibrinous pericarditis, signs of widespread renal cortical necrosis, and edematous acute pancreatitis. The brain weighed $1150 \mathrm{~g}$. Diffuse edema and brainstem herniation were seen. Microscopic findings were fibrinous pericarditis and epicarditis, sinovitis with mononuclear inflammatory infiltrate with lymphocytes and plasma cells, renal thrombotic microangiopathy with thickening of capillary walls, deposits of fibrin related materials in the capillary lumens, subendothelium, mesangium, interlobular and afferent arterioles, with aneurismatic dilatation of some of those vessels, thrombotic microangiopathy of the pancreas with fibrin deposits in the arterioles, leading to coagulative necrosis foci. Brain microscopic evaluation has disclosed fibrin related material deposits in the arterioles, accompanied by localized endothelial cell proliferation and detachment, and widespread necrosis foci.

\section{DISCUSSION}

The diagnosis of adult's Still disease in this case was based on the age of onset of symptoms, clinical picture, laboratorial data, and the exclusion of other diseases. Although there were several signs usually found in systemic lupus erythematosus, the possibility of this diagnosis was remote since antinuclear antibodies and serum complement were within normal values. The diagnosis of rheumatic fever was ruled out since anti-streptolysin $\mathrm{O}$ and echocardiogram were normal. This last finding as well as negative blood cultures excluded infective endocarditis. Three hypothesis were listed to explain the sudden neurological deteriorioration and the systemic complications: consumption coagulopathy, aspirin toxicity, and thrombotic microangiopathy.

Disseminated intravascular coagulation is a syndrome characterized by increased PA and APTT, decreased platelet count, and decreased levels of fibrinogen $^{3}$. Some cases of adult's Still disease associated with this coagulopathy have been described ${ }^{4}$. In this case, platelet count has decreased during the disease but fibrinogen level could not be assessed. However PA and APTT remained within initial levels even after the neurological deterioration. Since the coagulation tests abnormalities characterize this entity it is unlike this patient had disseminated intravascular coagulation. Also, thrombi in disseminated intravascular coagulation are usually predominant in the capillaries and aneurismatic dilatation of arterioles are not usually seen.

Aspirin toxicity has been described in association with adult's Still disease ${ }^{5}$. This condition is characterized by severe hepatotoxicity and disseminated intravascular coagulation. Although aspirin was introduced this association was ruled out since the patient had normal SGOT and SGPT levels and there were not hepatic disease at autopsy.

Thrombotic microangiopathies include thrombotic thrombocytopenic purpura (TTP) and Hemolytic Uremic Syndrome (HUS). These diseases show considerable overlap. TTP is classically a pentad of thrombocytopenia, microangiopathic hemolytic anemia, neurologic abnormalities, renal dysfunction, and fever. Hemolytic-uremic syndrome (HUS) is part of the spectrum of TTP-related disorders, defined by a triad of thrombocytopenia, microangiopathic hemolytic anemia, and renal dysfunction ${ }^{6}$. Idiopathic TTP and sporadic HUS, but not diarrhea, malignancy, or most drug-associated forms of TTP/HUS, are closely related in terms of response to therapeutic plasmapheresis and distribution of pathologic lesions, and they are now termed HUS/TTP syndrome. Three cases of TTP in patients adult's Still disease have been described. The first reported case with this rare association was a 45 year-old woman with a chronic adult Still's disease that has developed in that last thirteen years. 
After this time she has developed purpura, renal dysfunction, and altered level of consciousness. The post-mortem examination has revealed extensive thrombotic microangiopathy involving the lungs, heart, pancreas, thyroid, adrenal, lymphonodes, and bone marrow ${ }^{7}$. Two other cases without fatal outcome were reported. The first was a thirty-three yearold woman that presented clinical findings compatible with adult's Still disease and eight months later developed hemolytic anemia, severe thrombocitopenia, neurologic symptoms, and mild renal dysfunction. She was treated with exchange plasmapheresis, fresh frozen plasma infusions, methylprednisolone $250 \mathrm{mg} /$ day, and aspirin. Three days later the patient improved. The last case was a 28 year-old woman that developed adult's Still disease and five months later was admitted with microangiopathic hemolytic anemia, thrombocitopenia, polymorphonuclear leukocytosis, neurological findings, and mild renal failure. Treatment with fresh frozen plasma and high dose steroids was initiated and the patient was discharged home after 60 days $^{8}$.

All the cases with adult's Still disease and thrombotic microangiopathy were female patients. Our patient was younger than the other cases. In the other patients TTP has developed later in the course of adult's Still disease but our patient developed thrombocitopenia soon after the beginning of arthritis and fever. Indeed our patient has had a sudden evolution to coma with signs of brain herniation that was not observed in previous cases. To our knowledge this is the second description of a fatal disseminated thrombotic microangiopathy within cerebral vessels in a patient with ASD. Our patient was treated with aspirin and usual dose of steroids from the beginning of the hospital admission. When the clinical deterioration was seen high dose steroids associated with support measures like hyperventilation and dialysis were tried but they did not prevent death.

The thrombotic microangiopathies are characterized pathologically by the development of platelet microthrombi that occlude small arterioles and capillaries and clinically by microangiopathic hemolytic anemia and thrombocytopenia. Endothelial dysfunction plays a prominent role in the pathogenesis of HUS and TTP. Endotelial injury determines microangiopathy by endothelial denudation. Endotelial injury and activation triggers can be bacterial endotoxins, cytokines, viruses, drugs, and antiendothelial antibodies. Microangiopathy follows endothelial injury due to exposition of subendothelial thrombogenic substances, reduced production of prostaglandin 12 and nitric oxide enhancing platelet aggregation and causing vasoconstriction, increased adhesivity of activated endothelial cells to leukocytes, elaboration of abnormal multimers of Van Willebrand factor. More recently, plasma from patients with thrombotic microangiopathy has been reported to induce apoptosis in endothelial cells; the plasma factors responsible for these changes remain to be identified ${ }^{9-11}$. Adult's Still disease etiology remains unknown. Several isolated reports have suggested a viral trigger in the pathogenesis of ASD. Other possibility is that ASD is a non-necrotizing immune complex vasculitis. Some studies have found genetic predisposition and associations with HLA-DR2, DR-4, DR-7. The coexistence of these two disorders could be just a coincidence or they could share similar pathogenetic mechanisms. A viral trigger, antiendothelial antibodies, immune complex deposits, and cytokines production could theoretically be seen in and auto immune disease like ASD. One or several of these pathogenetic mechanisms could precipitate endothelial injury and activation that could determine the thrombotic microangiopathy. The association between thrombotic microangiopathy and other auto immune disorders like systemic lupus eritematosus, scleroderma, and Sjöegren's syndrome reinforces this possibility.

\section{REFERENCES}

1. Pouchot J, Sampalis JS, Beaudet F, et al. Adult's Still disease: manifestations, disease course, and outcome in 62 patients. Medicine 1991;70:118-136.

2. Reginato AJ, Schumacher HR Jr, Baker DG, Oçonnor CR, Ferreiros J. Adult onset Still's disease: experience in 23 patients and literature review with emphasis on organ failure. Sem Arthrits Rheum 1987;17:39-57.

3. Hardin RI. Disorders of the platelet and vessel wall. In. Fauci AS, Braunwald E, Isselbacher KJ, et al. (eds). Harrison's Principles of internal medicine, 14.Ed. New York: McGraw-Hill, 1998:730-736.

4. Silverman ED, Miller III JJ, Bernstein B, Shafai T. Comsumption coagulopathy assotiated with systemic juvenile rheumatoid arthritis. J Pediatrics 1983;103:872-876.

5. Sbarbaro JÁ, Bennet MB. Aspirin toxicity and disseminated intravascular coagulation. Ann Int Med 1977;86:183-185.

6. Umlas J, Kaiser J. Thrombohemolytic thrombocytopenic purpura: a disease or a syndrome? Am J Med 1970;49:723-728.

7. Masson C, Myhal D, Ménard H, Lussier A. Purpura thrombotique thrombopénique fatal chez une patiente atteinte dúne maladie de Still de l'adulte. Rev Rhum Mal Osteoartic 1986;53:389-391.

8. Boki KA, Tsirantonaki MJ, Markakis K, Moutsopoulos HM. Thrombotic thrombocytopenic purpura in adult Still's disease. J Rheum 1996;23:385-387.

9. Mitra D, Jaffe EA, Weksler B, Hajjar KA, Soderland C, Laurence J. Thrombotic thrombocitopenic prpura and sporadic hemolytic-uremic syndrome plasmas induces apoptosis in restricted lineages of human microvascular endothelial cells. Blood 1997;89:1224-1234.

10. Cines DB, Pollak ES, Buck CA, et al. Endothelial cells in physiology and in the pathophysiology of vascular disorders. Blood 1998;91:3527-3561.

11. Dang CT, Magid MS, Weksler B, Chadburn A, Laurence J. Enhanced endothelial cell apoptosis in splenic tissues of patients with thrombotic thrombocytopenic purpura. Blood 1999;93:1264-1270. 